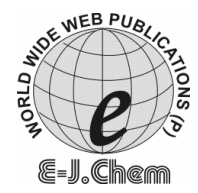

http://www.e-journals.net
ISSN: 0973-4945; CODEN ECJHAO

E-Journal of Chemistry

2009, 6(1), 207-212

\title{
Extractive Spectrophotometric Methods for the Determination of Etoricoxib in Tablets
}

\author{
KAMAL SHAH ${ }^{*}$, ALKA GUPTA $^{\S}$ and PRADEEP MISHRA ${ }^{\#}$ \\ \#Dr. Hari Singh Gour University, Sagar, (M.P.), India. \\ sIPS College of Pharmacy, Gwalior, (M.P.), India. \\ *GLA, Institute of Pharmaceutical Research, Mathura (U.P.), India. \\ kamal0603@gmail.com
}

Received 3 June 2008; Accepted 1 August 2008

\begin{abstract}
Two simple, rapid, sensitive, precise and economic spectrophotometric methods have been developed for the estimation of etoricoxib in tablet formulation. During the course of study, it was observed that acidic solution of the drug formed colored ion-association complexes with Bromocresol Green (BCG) and Bromocresol Purple (BCP) which were soluble in chloroform. This property of the drug was followed for the development of colorimetric methods for analysis of drug. The complex of etoricoxib with BCG and BCP showed $\lambda_{\max }$ at $416 \mathrm{~nm}$ and $408 \mathrm{~nm}$ respectively. These methods were validated statistically. Recovery studies gave satisfactory results indicating that none of common additives and excipients interfere the assay method. The proposed methods are found to be simple, accurate and reproducible that was successfully applied for the analysis of tablet formulation.
\end{abstract}

Keywords: Etoricoxib, Colorimetric analysis, BCG, BCP, Extractive spectrophotometry,

\section{Introduction}

Etoricoxib is 5-chloro-2-(6-methyl pyridin-3-yl) 3-(4-methyl sulfonyl phenyl) pyridine. It is used as a non-steroidal anti-inflammatory agent ${ }^{1}$. It has selective inhibition of COX-2 that decreases GI toxicity and without effects on platelet function ${ }^{2}$. It is commonly used for osteoarthritis, rheumatoid arthritis, primary dysmenorrhoea, post operative dental pain and acute gout. 
<smiles>COS(=O)(=O)c1ccc(-c2cc(Cl)cnc2-c2ccc(C)nc2)cc1</smiles>

Etoricoxib

The therapeutic importance of this drug has prompted the development of many methods for its assay. This drug is not official in any pharmacopoeia. Several methods have been reported for the analysis of etoricoxib in pharmaceutical dosage form as well as in the biological fluids and tissues, i.e. spetrophotometric methods ${ }^{3-4}$, chromatographic methods HPLC $^{5-7}$, LC/Mass spectrophotometry ${ }^{8-11}$. As there is no visible spectrophotometric methods for the analysis of etoricoxib in either biological fluids or pharmaceutical formulations were reported in the literature.

\section{Experimental}

\section{Apparatus}

A GBC Cintra 10 double beam UV-Visible spectrophotometer equipped with $10 \mathrm{~mm}$ matched quartz cells was used in the present investigation. A sartorius analytical balance was used.

\section{Reagents}

All chemicals used were of analytical reagent grade and double distilled water was used throughout. BCG and BCP reagent supplied by BDH chemicals, India. Aqueous solution of BCG $(0.1 \% \mathrm{w} / \mathrm{v})$, alkaline solution of BCP $(0.1 \%)$ and buffer solutions ${ }^{12}$ from 2.2 to $4 \mathrm{pH}$ were prepared. Etoricoxib as generously supplied by M/s Systopic Laboratories Pvt. Ltd., New Delhi, India was used as such without further purification. The commercially available tablets of etoricoxib were procured from local market labeled to contain $60 \mathrm{mg}$ etoricoxib/tablet.

\section{Preparation of standard solutions}

About $100 \mathrm{mg}$ of accurately weighed etoricoxib was dissolved in $100 \mathrm{~mL}$ of $0.1 \mathrm{~N} \mathrm{HCl}$ to get $1 \mathrm{mg} / \mathrm{mL}$ of standard stock solution. The working standard solution $(100 \mu \mathrm{g} / \mathrm{mL})$ for method A and B were prepared suitably by stepwise dilutions of the above stock solution with $0.1 \mathrm{~N} \mathrm{HCl}$.

\section{Procedure}

Varying quantities of working standard drug solution representing 2-18 and 4-20 $\mu \mathrm{g} / \mathrm{mL}$ of etoricoxib, $2 \mathrm{~mL}$ of dye solution (BCG or BCP), $3 \mathrm{~mL}$ of buffer solution ( $\mathrm{pH} 2.2$ ) were added finally volume made up with $0.1 \mathrm{~N} \mathrm{HCl}$, transferred into separating funnel, chloroform $(5 \times 2 \mathrm{~mL})$ was added to the separating funnel and contents were shaken for 2 minutes. The two phases were allowed to separate and the absorbance of the chloroform layer was measured at $416 \mathrm{~nm}$ and $408 \mathrm{~nm}$ for method $A$ and method B respectively, then calibration curve plotted for both $(2-18 \mu \mathrm{g} / \mathrm{mL}$ for BCG and $4-20 \mu \mathrm{g} / \mathrm{mL}$ for BCP). The sample solutions prepared were also treated in similar manner and the exact amount of etoricoxib present was deduced from the calibration graph. 


\section{Optimization of conditions}

Condition under which reaction of etoricoxib with dyes fulfils the essential requirements was investigated. All conditions studied were optimized at room temperature $\left(32 \pm 2^{0} \mathrm{C}\right)$.

\section{Selection of suitable $\mathrm{pH}$ buffer solution}

Buffer solutions of different $\mathrm{pH}(2.2,2.8$ and 4) were prepared. The stock solution was diluted with distilled water to give the drug concentration $100 \mu \mathrm{g} / \mathrm{mL}$. A $2 \mathrm{~mL}$ portion of this diluted solution was pipette out and added to three separating funnels. Two $\mathrm{mL}$ of BCG solution and $3 \mathrm{~mL}$ of buffers were added to each. Shaken well and extracted with $4 \times 2 \mathrm{~mL}$ of chloroform. Later the extracts were taken into $10 \mathrm{~mL}$ volumetric flasks and volume made up, then absorbances were measured at $416 \mathrm{~nm}$. Same procedure was applied for the BCP then absorbances were measured at $408 \mathrm{~nm}$. It was found that drug with BCG and BCP gave maximum absorbance at $\mathrm{pH} 2.2$ (Table 1).

Table 1. Optimization of parameters.

\begin{tabular}{|c|c|c|c|c|c|c|}
\hline \multirow{3}{*}{$\begin{array}{l}\text { Time, } \\
\text { min. }\end{array}$} & \multicolumn{6}{|c|}{ Absorbances } \\
\hline & \multicolumn{3}{|c|}{ BCG-Drug complex at different $\mathrm{pH}$} & \multicolumn{3}{|c|}{ BCP-Drug complex at different $\mathrm{pH}$} \\
\hline & 2.2 & 2.8 & 4 & 2.2 & 2.8 & 4 \\
\hline 0 & 1.0312 & 0.5601 & 0.5565 & 0.9526 & 0.6579 & 0.6586 \\
\hline 30 & 1.0296 & 0.5596 & 0.5419 & 0.9525 & 0.6220 & 0.6474 \\
\hline 60 & 1.0291 & 0.5589 & 0.5387 & 0.8439 & 0.6189 & 0.6419 \\
\hline 90 & 1.0294 & 0.5597 & 0.5308 & 0.8124 & 0.6070 & 0.6227 \\
\hline 120 & 1.0293 & 0.5011 & 0.5301 & 0.7929 & 0.6067 & 0.6221 \\
\hline
\end{tabular}

Stability study of drug dye complexes

The stability of the drug dye complexes was determined individually for both the dyes (BCG and BCP). A $2 \mathrm{~mL}$ portion drug concentration $100 \mu \mathrm{g} / \mathrm{mL}$ was pipette out and added to a separating funnel. Two $\mathrm{mL}$ of BCG solution $(0.1 \% \mathrm{w} / \mathrm{v})$ and $3 \mathrm{~mL}$ of buffers were added to each. Shaken well and extracted with $4 \times 2 \mathrm{~mL}$ of chloroform. Later the extracts were taken into $10 \mathrm{~mL}$ volumetric flasks and volume made up. The absorbances were measured periodically at an interval of 30,60, 90 and 120 minutes at $416 \mathrm{~nm}$. Same procedure was applied for the BCP then absorbances were measured at $408 \mathrm{~nm}$. Finally it was found that BCG drug complex was stable for $2 \mathrm{~h}$, whereas BCP drug complex was stable for more than $1 \mathrm{~h}$ and 30 min Table 1.

\section{Procedure for pharmaceutical formulation}

Twenty tablets were accurately weighed and powdered. The tablet powder equivalent to 60 $\mathrm{mg}$ of etoricoxib was extracted with methanol in $(4 \times 20 \mathrm{~mL})$ in $100 \mathrm{~mL}$ volumetric flask. This solution was suitably diluted with $0.1 \mathrm{~N} \mathrm{HCl}$ and then preceded as described above for pure drug. The nominal content of the tablets was determined either from the calibration curve or using the regression equation.

\section{Results and Discussion}

During the course of study, it was observed that acidic solution of the drug formed coloured ion-association complexes with bromocresol green and bromocresol purple which were soluble in chloroform. This property of the drug was followed for the development of colorimetric methods for analysis of drug. The complex of etoricoxib with BCG and BCP showed $\lambda_{\max }$ at $416 \mathrm{~nm}$ and $408 \mathrm{~nm}$ respectively. These developed for the estimation of 
etoricoxib from two formulations (ETOCOX and ETOBRIX). Both methods involve formation of ion-associated complex with BCG and BCP at pH 2.2 exhibiting $\lambda_{\max }$ at 416 $\mathrm{nm}$ and $408 \mathrm{~nm}$ respectively (Figure 1 and Figure 2). The method commonly used in the determination of certain amines and quaternary ammonium compounds that absorb weakly in the ultraviolet region ${ }^{13}$. The proposed method was based on addition of an amine in its ionized form to an ionized dye, yield a salt (ion-pair) that was extracted into an organic solvent such as chloroform or dichloromethane. The indicator dye was added in excess and the $\mathrm{pH}$ of the aqueous solution was adjusted to a value where both the amine and dye were in the ionized forms. The ion pair was separated from the excess indicator by extraction into the organic solvent. In these methods Beer's law was obeyed with BCG and BCP in the concentration range of $2-18 \mu \mathrm{g} / \mathrm{mL}$ and $4-20 \mu \mathrm{g} / \mathrm{mL}$ respectively. Optical characteristics of etoricoxib were given in the Table 2 .

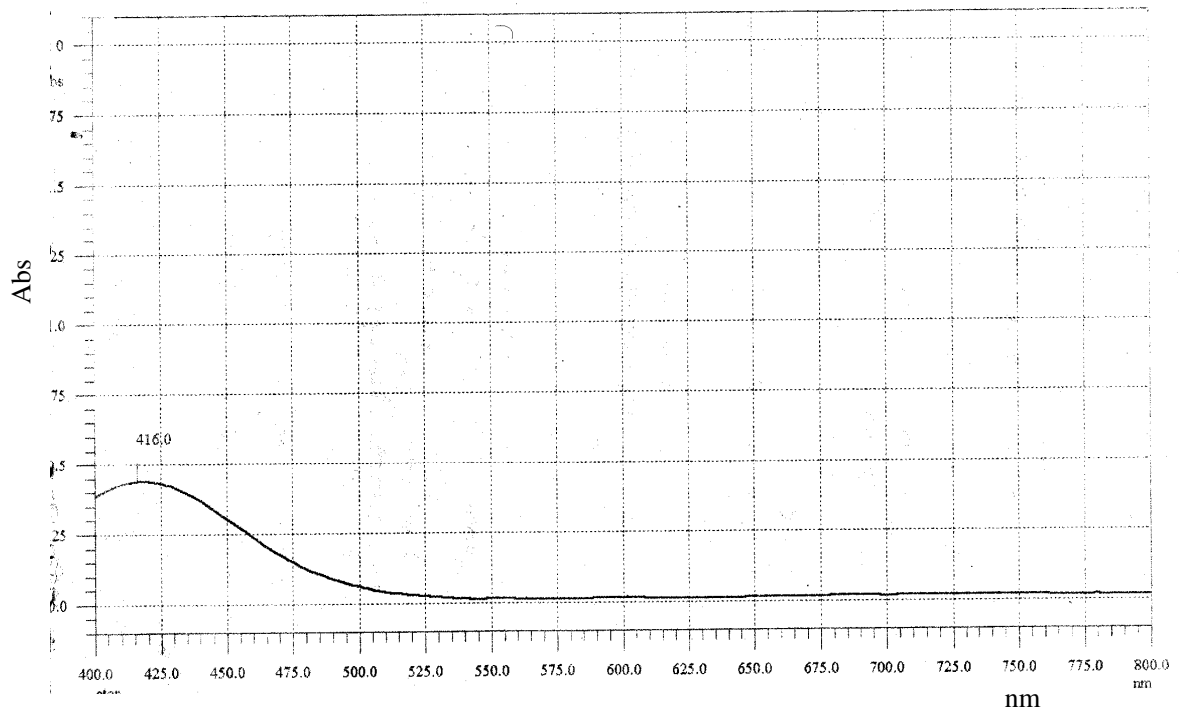

Figure 1. Colorimetric scan of drug-BCG complex.

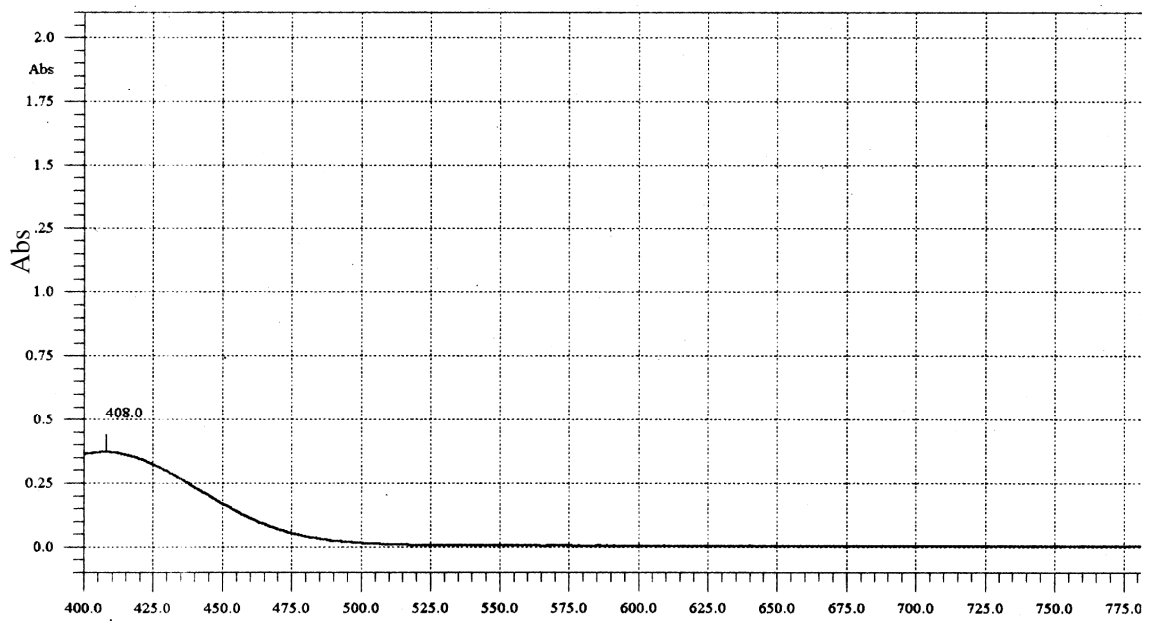

Figure 2. Colorimetric scan of drug-BCP complex. 
Table 2. Optical characteristics.

\begin{tabular}{lcc}
\hline Parameters & BCG & BCP \\
\hline$\lambda_{\text {max }}, \mathrm{nm}$ & 416 & 408 \\
Beer Lambert's law limits, $\mu \mathrm{g} / \mathrm{mL}$ & $2-18$ & $4-20$ \\
Molar absorptivity, $(\mathrm{L} / \mathrm{mol} / \mathrm{cm})^{*}$ & $1.9331 \times 10^{4}$ & $1.6642 \times 10^{4}$ \\
Sandell's sensitivity, $\mu \mathrm{g} / \mathrm{cm}^{2} / 0.001$ & 0.01856 & 0.02155 \\
Absorbance unit* & & \\
Regression equation $\mathrm{y}=\mathrm{mx}+\mathrm{c}$ & $\mathrm{y}=0.0512 \mathrm{x}+0.0193$ & $\mathrm{y}=0.0473 \mathrm{x}-0.0095$ \\
Slope $(\mathrm{m})$ & 0.0512 & 0.0473 \\
Intercept $(\mathrm{c})$ & 0.0193 & 0.0095 \\
Correlation coefficient $(\mathrm{r})$ & 0.9994 & 0.9992 \\
\hline
\end{tabular}

* Average of nine determinations.

The molar absorptivity and sandell's sensitivity showed that the methods were sensitive. The optimum conditions for colour development had been established by varying the different parameters involved. The result of analysis of commercial formulation significantly showed low values for standard deviation, standard error of mean, coefficient of variance and percentage range of error (within 95\% confidence limits), thus showed precision of the methods given in Table 3. For testing the accuracy and reproducibility of the proposed methods, recovery studies were performed. The data obtained by recovery studies indicate non-interference from the excipients used in the formulation shown in Table 4. The percentage recoveries were close to $100 \%$. This study revealed that the common excipients and other additives such as lactose, starch, gelatine, talc and magnesium stearate that are usually present in the tablet dosage forms do not interfere in the analysis. Thus, it can be concluded that the proposed methods are found to be simple, rapid, sensitive and accurate that can be used for the determination of etoricoxib in their pharmaceutical dosage forms in a routine manner.

Table 3. Statistical analysis of commercial formulations.

\begin{tabular}{lcccccccc}
\hline Method & Brand & $\begin{array}{c}\text { Amount } \\
\text { Proposed } \\
\mathrm{mg} / \mathrm{tab}\end{array}$ & $\begin{array}{c}\text { Amount } \\
\text { found } \\
\mathrm{mg} / \mathrm{tab}\end{array}$ & $\mathrm{SD}^{*}$ & $\mathrm{COV}^{*}$ & $\mathrm{SE}^{*}$ & $\begin{array}{c}\mathrm{t}^{*} \\
\text { Calcd }\end{array}$ & $\begin{array}{c}\mathrm{t}^{*} \\
\text { Theor }\end{array}$ \\
\hline $\mathrm{A}$ & ETOCOX & 60 & $59.99 \pm 0.03$ & 0.0404 & 0.0673 & 0.0164 & 0.6063 & \\
& ETOBRIX & 60 & $60.00 \pm 0.04$ & 0.0606 & 0.1009 & 0.0247 & 0.8084 & \\
$\mathrm{~B}$ & ETOCOX & 60 & $60.01 \pm 0.04$ & 0.0622 & 0.1036 & 0.0253 & 0.3938 & \\
& ETOBRIX & 60 & $60.00 \pm 0.06$ & 0.0828 & 0.1379 & 0.0338 & 0.1774 & 1.476 \\
\hline
\end{tabular}

* Average of six determinations

$S D=$ Standard deviation, $C O V=$ Coefficient of variation, $S E=$ Standard error, $*$ Theoretical ' $t$ ' values are calculated at $95 \%$ confidence level for $(n-1)$ degrees of freedom ' $t$ ' $(0.10,5)=1.476$

Table 4. Drug recovery studies.

\begin{tabular}{clc}
\hline Method & \multicolumn{1}{c}{ Brand } & \% Recovery \pm S.D.* \\
\hline A & ETOCOX & $99.73 \pm 0.11$ \\
& ETOBRIX & $99.91 \pm 0.10$ \\
B & ETOCOX & $100.04 \pm 0.13$ \\
& ETOBRIX & $100.08 \pm 0.13$ \\
\hline \multirow{3}{*}{ * Average of six determinations } \\
S. D : Standard Deviation
\end{tabular}




\section{Acknowledgements}

The authors are thankful to M/s Systopic Laboratories Pvt. Ltd., New Delhi for providing gift sample of etoricoxib for research; to the Head, Department of Pharmaceutical Sciences, Dr. H.S. Gour University, Sagar, M.P. for providing facilities. The financial assistance received from AICTE (New Delhi) in the form of fellowship for post-graduate studies in Engineering and technology is being gratefully acknowledged by the authors Kamal Shah and Alka Gupta.

\section{References}

1. Sweetman S C Ed., In; Martindale: The Complete Drug Reference. Royal Pharmaceutical Society of Great Britain, 2005, 38.

2. Agrawal N G B, Porras A G, Mathews C Z, Woolf E J, Miller J L, Mukhopadhyay S, Neu D C and Gottesdiener K M, J Clin Pharmacol., 2001, 41, 1106.

3. Singh R M, Kumar Y, Sharma D K, Mathur S C, Singh G N, Ansari T A and Jamil S, Indian Drugs, 2005, 42(8), 56.

4. Suhagia B N, Patel H M, Shah S A, Rathod I S and Marolia B P, Indian J Pharm Sci., 2005, 67(5), 634.

5. Hartman R, Abrahim A, Clausen A, Mao B and Crocker L S, J Liq Chrom Relat Tech., 2003, 26(15), 2551.

6. Mandal V, Rajan D S, Bose A, Gowda K V, Ghosh A and Pal T K Indian J Pharm Sci., 2006, 68(4), 485.

7. Rose M J, Agrawal N, Woolf E J and Matuszewski B K, J Pharm Sci., 2002, 91(2), 405.

8. Brautigam L, Nefflen J U and Geisslinger G, J Chromatogr B Analyt Technol Biomed Life Sci., 2003, 25, 788(2), 309.

9. $\quad$ Brum Jr L, Fronza M, Ceni D C, Barth T and Dalmora S L, J AOAC Int., 2006, 89(5), 1268.

10. Ramkrishna N V S, Vishwottam K N, Wishu S and Koteshwara M, J Chromatogr., $B$ 2005, 816(1-2), 215.

11. Werner V, Werner D, Hinz B, Lambrecht C and Brune K, Biomed Chrom., 2004, 19 (2), 113.

12. Indian Pharmacopoeia, $3^{\text {rd }}$ Ed., Vol. 2, Controller of Publications, New Delhi 1985:A-142.

13. Sastry C S P, Petla N Y and Murthy S S N, Indian J Pharm Sci., 1997, 59(3), 124. 


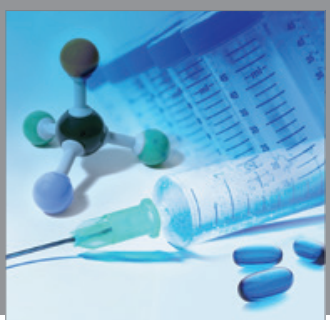

International Journal of

Medicinal Chemistry

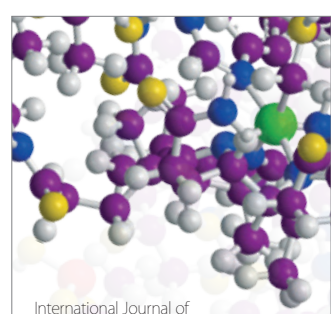

Carbohydrate Chemistry

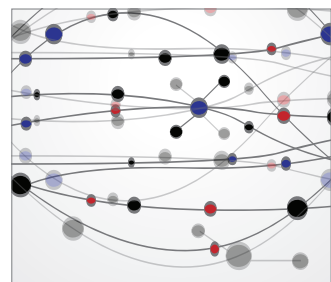

The Scientific World Journal
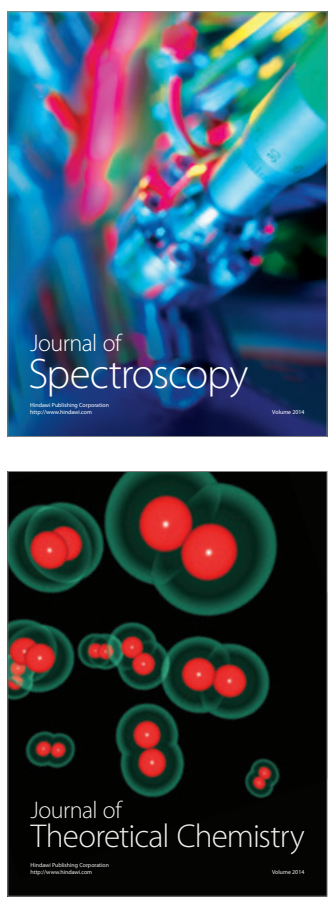
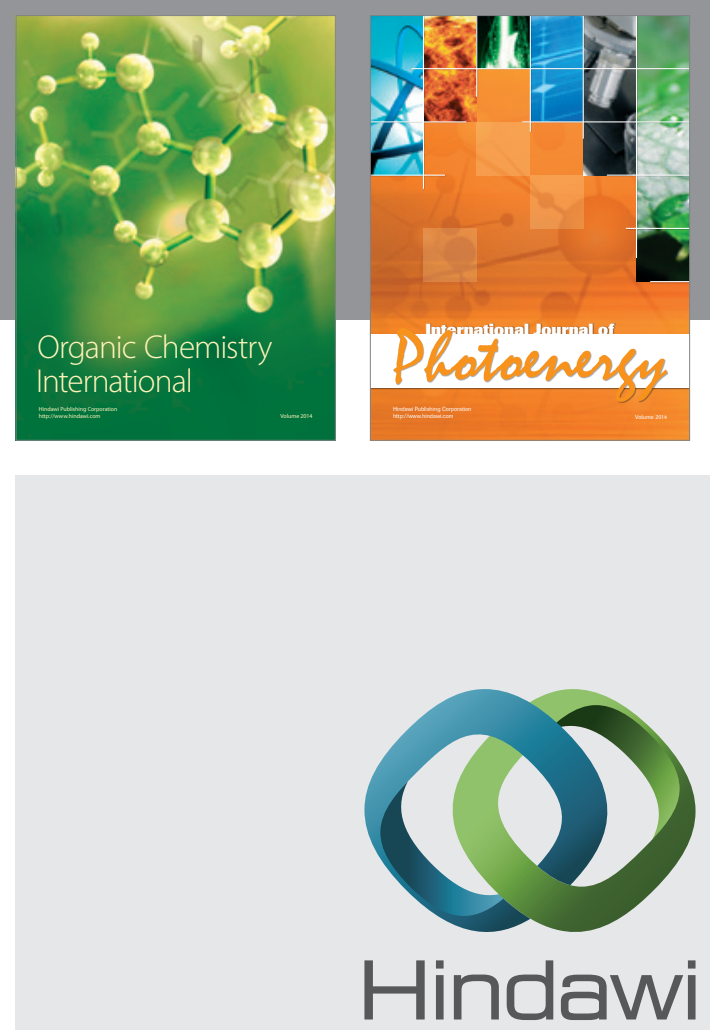

Submit your manuscripts at

http://www.hindawi.com
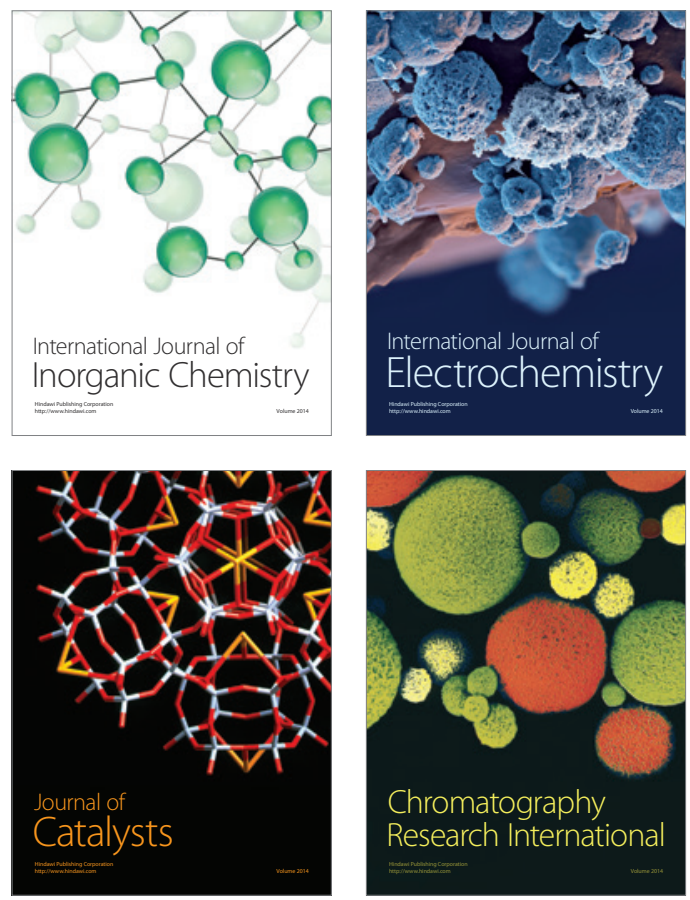
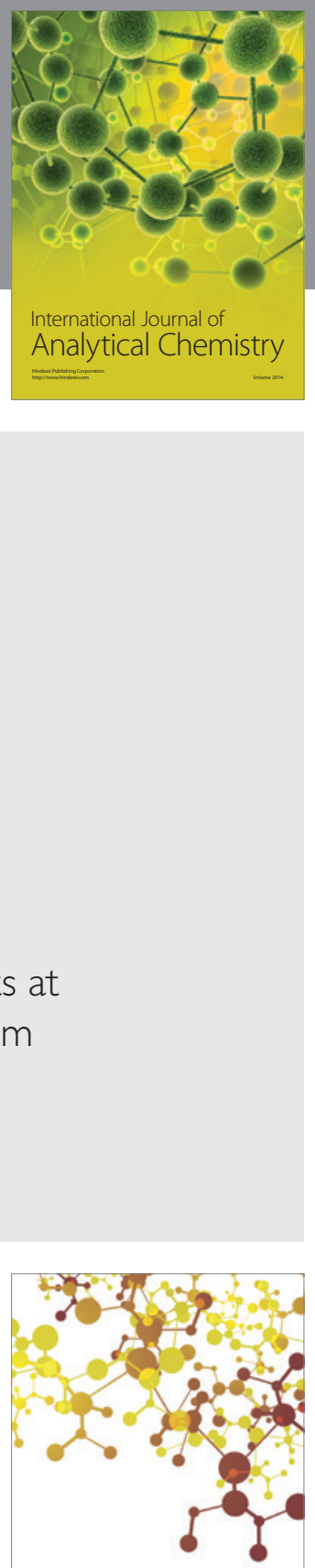

Journal of

Applied Chemistry
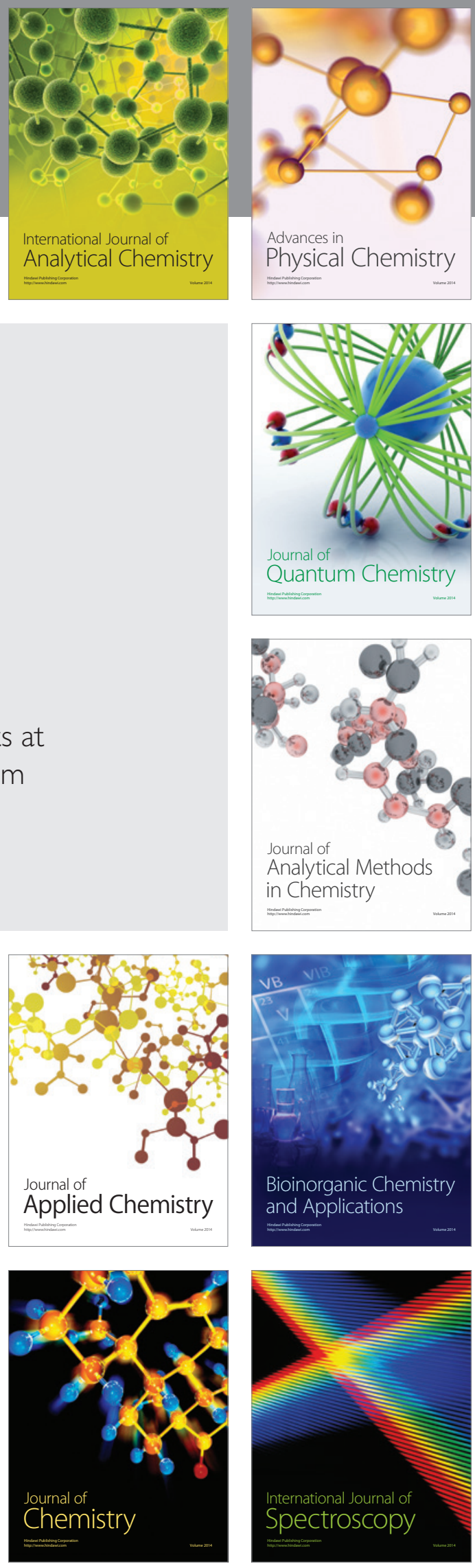